\title{
Why Finland's running circles around us
}

Written by: Christopher Palmberg, Business Finland

Last update: 4 March 2019

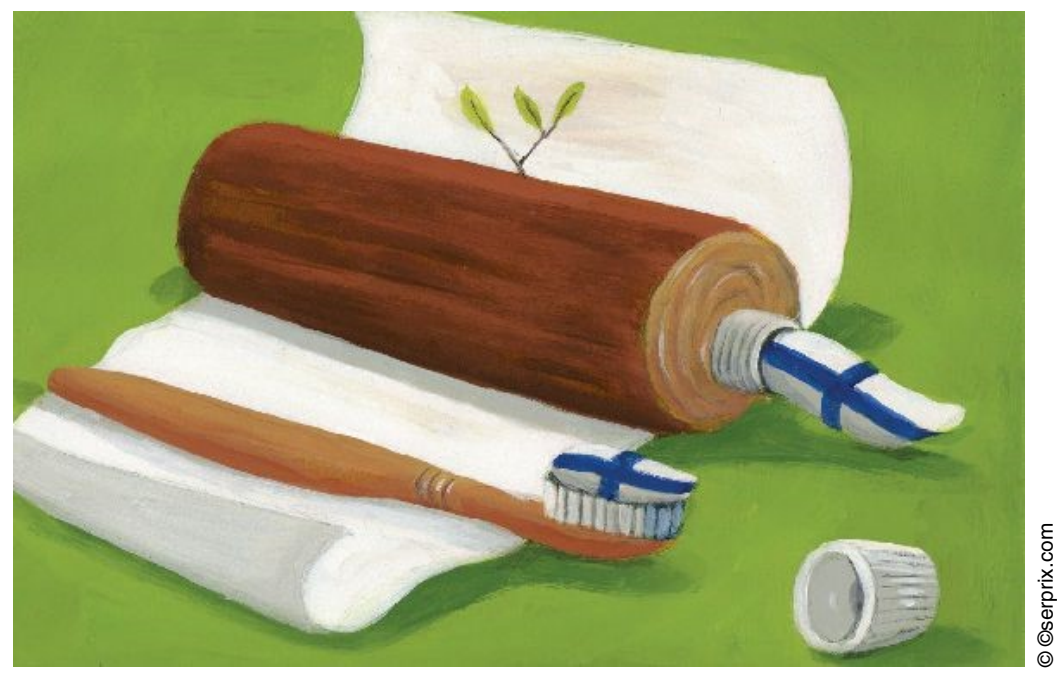

What do toothpaste and ice-cream have to do with a circular economy? If you live in Finland, quite a lot. CP Kelco, a multinational company with facilities in Äänekoski, Finland, recycles waste pulp from the city's pulp and paper mill into carboxymethyl cellulose, a natural polymer used to thicken icecream and toothpaste.

Minimising waste or converting it into useful products like this is one of the three central tenets of a circular economy. The other two are processing products in the most resource-efficient way and making things that have a much longer life-span -disposables are the villains in a circular economy. And, when manufacturing uses biological raw resources or biotechnological means in the process, as is the case with CP Kelco's toothpaste and ice-cream, what is circular is not just the economy but the bioeconomy.

Due to climate change and resource depletion, we need to redesign industrial processes to reduce carbon emissions, waste, and contaminants. Finland is embarking on this, making it one of the great champions of a circular economy. It was the first to create a national circular economy roadmap, in 2016, and is one of $7 \mathrm{EU}$ member states to have a dedicated bioeconomy strategy. It hosted the first world circular economy forum, with 90 countries attending, in 2017. Its innovation fund, SITRA, together with the European Climate Foundation (ECF), 
then commissioned a report, 'Re-configure: The Circular Economy-a Powerful Force for Climate Mitigation', which was released last year. Its findings were radical: switching to a circular industrial production of cement, steel, aluminium, and plastics, particularly in the construction and passenger car industries, could reduce EU industrial emissions each year by 56\% (296 million tonnes of CO2 out of a total of 530) by 2050. This could take the EU more than halfway towards net zero emissions.

Finland can show us the way. One of the most advanced bioeconomies in the world, Finland's forestry sector accounts for over $20 \%$ of its export revenue, and over half of the Finnish bioeconomy. Other than toothpaste and ice-cream thickener, another use of timber and forest residues is pulp-based fabrics, which is a burgeoning new industry. The Metsä Group pulp and paper mill, for one, is experimenting with this, also in Äänekoski.

Finland, of course, continues to manufacture paper from wood though this is an industry that has been troubled by the transition to paperless digital media. Still, $25 \%$ of the paper industry's value-added is now achieved through circular bioeconomic processes. Biodegradable packaging and bio-based chemicals, plastics and, as mentioned earlier, textiles, are just some novel products of waste streams from paper manufacturing. But it is the replacement of high carbonemitting, high energy-use cement with renewable timber in large-scale building construction that will make the biggest dent in the country's carbon budget. In 2011 the Finnish government set a target of increasing the market share of domestically-sourced wood multi-storey construction from 1\% in 2011 to $10 \%$ by 2015. In 2015, an 8-storey timber-frame building was completed in Finland, one of the first high-rise examples of prefabricated cross-laminated timber (CLT) construction in the world.

Finland's investment in bioeconomy is such that it now represents $16 \%$ of the national economy. And the Finnish bet is paying off handsomely: besides conjuring economic wealth from things previously thrown away, it has also created jobs. In 2014, the bioeconomy generated revenues exceeding $€ 60$ billion with more than 300,000 people employed in it. Finland aims to bring this number up to $€ 100$ billion by 2025 and add another 100,000 jobs-a growth of about $4 \%$ a year. And beyond that? Estimates suggest another $€ 2-3$ billion in potential added value to the Finnish economy by 2030 . And another 75,000 additional jobs as the economy gets more and more circular.

What is truly groundbreaking, however, is the way in which Finland is pioneering new circular bioeconomy business models. It is creating circular bioeconomy hubs around biorefineries. These are the 'factories' of the bioeconomy, which convert raw materials like wood into products like fuels, chemicals, plastics and textiles. Finland has been savvy in embedding their biorefineries geographically within an ecosystem or cluster of companies. The biorefineries are close to the feedstock; in Finland, this is more often than not, forests. The bioproduction mills 
convert this feedstock and feedstock waste into fuel or chemicals that the nearby companies use in creating their own products. These are then consumed locally or exported, and eventually, when products have reached the end of their life, recycled. Äänekoski, with its traditional pulp mills, is one such hub. Metsä Group has developed a $€ 40$ million test plant in Äänekoski that is experimenting with converting paper-grade pulp into fabric. The Metsä Group hub also includes two chemical plants: CP Kelco, mentioned above, and Minerals Nordic, as well as the Valio cheese factory. Valio makes use of the heat generated by a pulp mill in its cheese production. Other typical pulp mill by-products are tall oil, which is used in adhesives, rubbers, inks, soaps, lubricants, and emulsifiers and the turpentine found in solvents, paint-thinners and fragrances.

Äänekoski has been so successful that it is pursuing even more circular bioeconomy business opportunities. EcoEnergy SF now produces a unique biogas as well as biofuel pellets from the mill's wastewater treatment plant sludge. Another company, Aqvacomp, may build a plant at Äänekoski that processes pulp into a biocomposite that can replace plastic in the electronics and automotive industries. And lastly, the mill itself gasifies tree bark into a bio-based natural gas to fuel the mill, replacing fossil-fuel energies. It captures a portion of its $\mathrm{CO} 2$ emissions, converting them into pigments, and has pioneered a process by which it converts noxious gases into sulphuric acid for the mill's own use-a world first.

Äänekoski aims to create bioproducts that use $100 \%$ of its raw wood and production side streams. This will create some 2,500 new jobs and a whole lot less carbon emissions. Bioindustrial clusters like Äänekoski are the future, now. With refineries that are close to feedstock and companies that produce goods for local and export consumption, these hubs create ecologically virtuous circles. Äänekoski shows that if, like in Finland, there is the political will, there will be a circular bioeconomy way.

This article is part of a series celebrating Finland's 50th anniversary as a member country of the OECD:www.oecdobserver.org/finland50oecd @OECD Observer March 2019

๑OEECD Observer March 2019

\section{References}

Philp, J. and D. Winickoff (2018), Realising the circular bioeconomy, OECD Science, Technology and Industry Policy Papers, No. 60, OECD Publishing, Paris http://dx.doi.org/https://doi.org/10.1787/31bb2345-en

OECD (2019), "Innovation for a sustainable bioeconomy: innovation ecosystems", OECD Publishing, Paris, forthcoming http://dx.doi.org/OECD (2019), "Innovation for a sustainable bioeconomy: innovation ecosystems", OECD Publishing, Paris, forthcoming

Wijkman, Anders and Skånberg, Kristian (2015), "The circular economy and benefits for society. Jobs and climate clear winners in an economy based on 
renewable energy and resource efficiency. A study pertaining to Finland, France, the Netherlands, Spain and Sweden." Club of Rome, Winterthur, Switzerland http://dx.doi.org/Wijkman, Anders and Skånberg, Kristian (2015), "The circular economy and benefits for society. Jobs and climate clear winners in an economy based on renewable energy and resource efficiency. A study pertaining to Finland, France, the Netherlands, Spain and Sweden." Club of Rome, Winterthur, Switzerland

European Commission (2018), "A sustainable bioeconomy for Europe:

strengthening the connection between economy, society and the environment", European Commission, Brussels http://dx.doi.org/European Commission (2018), "A sustainable bioeconomy for Europe: strengthening the connection between economy, society and the environment", European Commission, Brussels

Finnish Bioeconomy Strategy (2014), Ministry of Employment and the Economy https://www.biotalous.fi/

Hetemäki, L., Hanewinkel, M., Muys, B., Ollikainen, M., Palahí, M. and Trasobares, A (2017), "Leading the way to a European circular bioeconomy strategy", From Science to Policy 5, European Forest Institute http://dx.doi.org/ Hetemäki, L., Hanewinkel, M., Muys, B., Ollikainen, M., Palahí, M. and Trasobares, A (2017), "Leading the way to a European circular bioeconomy strategy", From Science to Policy 5, European Forest Institute

International Renewable Energy Agency (2018), "Bioenergy from Finnish forests: Sustainable, efficient and modern use of wood", International Renewable Energy Agency, Abu Dhabi. ISBN 978-92-9260-012-9 http://dx.doi.org/ International Renewable Energy Agency (2018), "Bioenergy from Finnish forests: Sustainable, efficient and modern use of wood", International Renewable Energy Agency, Abu Dhabi. ISBN 978-92-9260-012-9

OECD (2018), Meeting Policy Challenges for a Sustainable Bioeconomy, OECD Publishing, Paris http://dx.doi.org/https://doi.org/10.1787/9789264292345-en

Sitra (2016), "Leading the cycle: Finnish road map to a circular economy 20162025", Sitra Studies 121, ISBN 978-951-563-978-3. http://dx.doi.org/Sitra (2016), "Leading the cycle: Finnish road map to a circular economy 2016-2025", Sitra Studies 121, ISBN 978-951-563-978-3. 